\title{
Hinduism and Women Religious Beliefs and Practices
}

\author{
Hari Priya Pathak \\ Ph.D, Department of English, D.S.B. Campus, Kumaun University, Nainital, Uttarakhand, India \\ haripriyapathak@gmail.com
}

\begin{abstract}
Religion plays a significant role in structuring and maintaining a society by enforcing certain morals and norms. Like any other religion, Hinduism has guided the Hindus to live in a particular way since time immemorial. India is predominantly a Hindu society and Hinduism has had a huge impact on the structure, function and culture of Indian societies. Ancient Hindu scriptures like the Vedas and Upanishads show profound respect for the feminine principle. It is the Supreme Being, from who all emanate. A woman is a Goddess to be worshipped. During ancient times, the condition of women was in conformity with the religion and they enjoyed freedom, equality and liberty in all spheres of life. However, subsequently, the emergence of texts like the Epics, Smritis, Sastras, vernacular writings and oral traditions, redefined an ideal woman and led to the practices where women were subservient to men. This dissonance and conflict between religious beliefs and practices has strengthened in present times, and has witnessed a steep rise in the number of crimes against women. Increasing domestic violence, sexual violation, female feticide, dowry deaths, declining ratio of women and men and the taboos (arising from having a female body, such as, menstruation) are causing not only distress but also widespread criticism and revolt among women and society at large. Despite the Indian Constitution rejecting any kind of discrimination against women and deeming it unlawful, these inhuman atrocities against women are on the rise. More than ever, there is a need to take refuge in the religion (early Vedic period), not to be too staunch, but to be flexible, democratic and liberal in our outlook with dynamic times and ever shifting contexts. This paper proposes to study (with particular reference to India), the religious beliefs in Hinduism concerning women, and the gradual discord between the beliefs and practices leading to discrimination against women in many spheres today.
\end{abstract}

KEYWORDS: religion, Hinduism, Vedic Period, culture, scriptures, beliefs, practices

\section{Introduction}

Every society is heterogeneous and is governed by norms or laws regarding duties, morality, virtues, rights, behaviour, and many more things for maintaining order and stability. These norms evolve gradually from the earliest institutions which distinguish human societies from animal kingdom. Simone de Beauvoir $(1997,84)$ in her famous book The Second Sex states, 'Humanity is not an animal species, it is a historical reality,' History plays an important role in tracing the development of any society. Women who form an integral part of the society, too, can be studied historically. Considering the study of women in Hinduism, it becomes imperative to take into account both religiohistorical factors which affected the status and perception of women by men as well as by women themselves, then and onwards. Hinduism, as a way of life has been governed and structured by the earliest scriptures like Vedas, Upanishads, Smritis and Puranas. Cultural practises, beliefs, attitudes, points of view in Hinduism are thus governed directly or indirectly by these scriptures. However, the role of history cannot be undermined. The condition of women in today's Hindu societies, therefore, is undoubtedly an outcome of both religion and history. Historical forces deepened, distorted, modified, and appropriated what the early Vedic scriptures had directed. The early Vedic religion, known to be the foundation of Sanatan Dharma (Hinduism), and Vedic philosophy has had the most profound impact on Hinduism. Unfortunately Vedic philosophy was distorted and made compatible and advantageous for particular races as well as powerful kings and certain sections of the society predominantly constituted of men. Thus, to say that women in Hindu societies have always been subservient to men, or were differentiated on the bases of gender will not be true. In Hinduism, the position of women varies greatly from one historical period to another. Also, there is a conflict between the depiction of women in scriptures and in reality. Ancient Hindu scriptures like the Vedas and Upanishads show profound respect for the feminine principle. It is the Supreme Being, from whom everything emanates. She is Shakti in the form of Durga, Goddess of Knowledge as Saraswati and the Goddess of Wealth as Laxmi. All the life giving rivers are feminine and are to be venerated. Nonetheless, in actuality, women have always been discriminated and suppressed since long. 
This paper discusses the disparities between Hindu beliefs and practices concerning women and explores the religiohistorical factors that lead to the contemporary perception and position of women in Hindu society.

\section{Women in Early Vedic Period}

The Vedic Period which spanned from $1500 \mathrm{BCE}$ to $600 \mathrm{BCE}$ can be divided into early Vedic Period (1500 BCE -1000 BCE) and later Vedic Period (1000 BC -600 BC). It is noteworthy that women enjoyed more or less the same status as men during the early Vedic Period. They underwent Upanayan Sanskaar (a ceremony to begin with formal education) just like men, were free to choose between higher studies (philosophy and logic) to become Brahmavadini, or become Sadhyavadhu to marry and look after the household and family. These two institutions were open for both young men and women. Like the male sages and gurus, there were female sages and Upadhayayas (women gurus) who took part in most of the religious rites and rituals. The primal energy which formed the cosmos was the feminine principle. She was worshipped and feared too. Some well-known women-seers who composed several hymns in RgVeda during early Vedic Period are Mamta, Romsha, Lopamudra, Aditi, Apala and Shikhandini.

In early Vedic period, the Rg Veda, child marriage is not mentioned. The girl was free to choose her match, and dowry was unknown, except that it was offered if the girl had some physical defect or the bride money was paid if the groom was less qualified (Das 1993, 58). Even widow remarriage was permissible in Vedic period.

But the desire to get a son and not a daughter, (which became very prominent later) is very apparent through the hymns in $\mathrm{Rg}$ Veda, in this period too. These hymns invoking gods like Indra, Soma and Varuna during rituals, which were very common during that period, aimed at attaining wealth along with intelligent, valorous, and strong sons and grandsons. (Rg Veda. Part II 3:4:9, $3: 6: 1,3: 10: 3,3: 13: 7,4: 3: 5,4: 4: 11,5: 61: 3)$. This could very well be attributed to the perpetuality of wars and the high demand of male warriors to protect the kingdoms, clans and families. Women are mentioned scantly, that too only as a mothers (mainly Aditi who is the mother of valorous men) and as wives.

It must be noted that during the early Vedic Period, when wars and skirmishes were frequent among groups, the need for warriors was a necessity. This need of the society was fulfilled by women, and thus the reason for women's respect, and the consent for widow remarriage. It is clear in the hymns where nature (in the form of gods) is invoked to help them destroy their enemies, fulfil their vessels with grains, grant them wealth and strong sons. Women, in these hymns are mentioned as goddess, mothers or truthful wives only (Atharva Veda. Part II. 20:126:6,9,10). All this changed drastically in the later Vedic Period, when Aryans had more or less established themselves in the northern parts of the Indian subcontinent.

\section{Women in Later Vedic Period}

Another collection of religious texts, philosophical in nature, having tremendous effect on the Hindu philosophy are Upanishads, written probably between 800 BCE-500 BCE. It is in these texts where the Brahaman and the Atman appears. Matters of spirituality and concern about birth, karma, rebirth, salvation and meditation are forcefully discussed here. In the later Vedic Period women had begun to lose the position acquired during early Vedic Period. We know this through the stories that women, though important, were given away by their fathers as gifts to oblige other men or power and position. However, there still were women like Gargi, Maitreyi, Usati, Satyakama who took part in spiritual debates along with men and composed hymns. Noteworthy is the Pavamana Mantra (Om asato ma sad gamaya...) from Brhadaranyaka Upanishad, which was valued much among all the prayers in the Parliament of World Religions in Chicago in 1893, was composed by Brahmavadini Maitreyi (Tandon 2016, 15).

The later Vedic Period spanning from 1000 BCE- 600 BCE, is the period of Dharmasastras, Smritis including Puranas, Ramayana and Mahabharat which contain the renowned philosophy of Bhagavadgita. This period witnessed social stratification in the form of caste system (still present in 
Hinduism), based on inheritance, birth rights and privileges. It was different from the early Vedic Period, where the social stratification in human society (Varna system) was based on colour, class, individual capacity, occupational aptitude, and moral and intellectual worth (Kane 1974, 82-86). Later Vedic or Post-Vedic scriptures like the Dharmasastras and Manusmriti codified the laws and commented upon the duties and social behaviour towards the society, family and oneself. Murray (1994, 206-207) has listed some of the features of the caste system stated by Manu which have formed the basis of the social practices. These are:

- Continuous cultural prominence of the Brahmins in religious rituals

- Caste system based on birth and inheritance

- Prohibition of mobility across the caste boundaries, to be maintained strictly by regulating marriages and eating arrangements

- Centrality of rituals for maintaining social stratification based on the concept of Dharma.

Smritis, especially Manusmriti is known for its injunctions on morality and social codes pertaining to women, which are still considered as the gold standards for women's responsibilities, attitude, behaviour and conduct towards the society, family and oneself. Manusmriti has several contradictory statements that shift from derogatory remarks to glorification of women. Some noteworthy examples are as follows:

- Her father protects (her) in childhood, her husband protects (her) in youth, and her son protect (her) in old age; a woman is never fit for independence (Buhler 1886, IX, 3).

- She who, controlling her thoughts, speech, and acts, violates not her duty towards her lord, dwells with him (after death) in heaven, and in this world is called by the virtuous a faithful (wife, sadhvi) (Buhler 1886, IX, 29).

- But for disloyalty to her husband a wife is censured among men, and (in her next life) she is born in the womb of a jackal and tormented by diseases, the punishment of her sin (Buhler 1886, IX, 30).

Contradictory to this, he glorifies women:

- Where women are honoured, there the gods are pleased; but where they are not honoured, no sacred rite yields reward (Buhler 1886, III, 56).

- The houses on which female relations, not being duly honoured, pronounce a curse, perish completely, as if by magic (Buhler 1886, III, 58).

The custom of Sati (burning oneself in one's husband's pyre), and which later grew tremendously (but is totally obsolete in current times), is nowhere mentioned in Vedic texts. There was a gradual deterioration in the condition of not only the widows who were expected to live a life of strict austerity and self-denial but also in the general condition of women too. The concept of Stridhan (which later became dowry) also comes into being by the later Vedic Period, which refers to land, money or other gifts like ornaments given to a woman during her marriage for her future maintenance. Puranas, another Vedic text, deal with several myths and legends. Some of these Puranas are named after the deities like Shiva, Vishnu and Devi (especially Durga). These can be taken as reflection of the socio-cultural scenario of their times, and thus throw light on the condition of women. By the end of the Vedic period and dawn of the Puranas, girls were forced into marriage even before they attained puberty. According to Vishnu Purana, after completing his education, a man should marry a maiden who is a third of his age. Thus, a man of thirty years of age must marry a girl of ten. It's also mentioned that the girl must worship him with white flowers, should be attentive to all his requirements and must try to keep him happy at any cost (Roy 2012, 128). The text of Skanda Purana also mentions that a wife should never utter the name of her husband if she wants a long life for him (practice is still prevalent). Other Puranas like Garud Purana too is full of such directions for a wife, and also the importance of begetting a son for attainment of heaven and salvation. It says, 'How do you desire to attain heaven without begetting a son, worshipping gods and without offering prayers (Pind daan) to your ancestors? $(2010,136)$.' By the time of Puranas, between $750 \mathrm{BCE}$ and $350 \mathrm{BCE}$ (later collected between the fourth and sixth century AD under Gupta dynasty), the society had become fully patriarchal and the matters regarding women were perhaps settled and carried on further till the contemporary times. These beliefs were reinforced through 
several texts as well as practices. The condition of women was no less than animals, which could be sold and bought or given away as gifts. The treatment of women as mere commodities can also be attributed to the establishment of Aryans in the northern region of India and the absorption of non Aryans into the social framework of the Aryans as Sudras who fulfilled the requirement of cheap labour, as well as an abundant source of available women. These factors combined together with the spiritual texts, drastically eroded the value of women and the independence she had once enjoyed, leading to gender polarity. Tharu and Lalita $(1991,54)$ write, 'The Vedic idealism was itself shaped by the struggle against matriarchal materialistic cultures and still carries the mark of the engagement.'

\section{Therigathas (Verses of the Elder Nuns)}

The sufferings of women led them to surrender to Lord Buddha (around $600 \mathrm{BCE}$ ), and it is in the Therigathas or the poems (translated as Verses of the Elder Nuns), that pain, revolt and the spiritual opportunity of these women through Dhamma and Sangha of Buddhism is readily apparent. For instance, in the following therigatha, one of the bhikkhunis, satirizing upon the false beliefs and rituals common in Hinduism writes:

Who taught you this

- the ignorant to the ignorant -

'One through water ablution,

is from evil kamma set free?'

In that case they would all go to heaven:

all the frogs, turtles, serpents, crocodiles,

$\&$ anything else that lives in the water.

Another therigatha clearly shows not only the predicament of a widow woman but also reflects upon the importance of a son, without whom a woman is doomed.

I was poor in past, widow and without sons;

Without friends and relatives, I didn't acquire food and

clothes.

Holding the bowl and walking stick, begging alms from

family to family;

Burning by heat and cold, I dwell for seven years.

(Translated by Bhikkhu 2005)

\section{Women in Later Periods}

During the later periods of Indian history, some of the beliefs and rituals relating to salvation had already given primacy to a son over a daughter. A daughter could only hold a right to private property in the absence of a son. It was the son and not the daughter who could perform the last rites of his dead parents and could perform 'shraddha' and 'Pind daan', required for the salvation of his parents. It must be noted that these performances were prohibited in Vedas and the Gita but can be seen in Puranas. Garuda Purana says, “...there is no salvation for a man without a son” (Singh 2004, 62).

Other than this, there were common traditional practices based on discrimination because of the birth and gender (which are still seen). It is generally agreed that the basis of caste system is determined by the notions of purity and pollution. 'All margins....and matters issuing from them (peripheral extremities of the human body) are considered polluting...hair, nails...spittle, blood, semen, urine, faeces or even tears' (Murray 1994,174). This belief naturally keeps the Brahmins in the highest pedestal performing religious activities, whereas the Sudras (the lowest in the hierarchy of caste system) are defiled because of the menial jobs they perform/ed. Apart from this, women too are considered impure not only because of the cyclical process of menstruation but also because of the child birth.

All these false beliefs (as they were not mentioned in the early Vedas, called Sanatan Dharma) and the practices which had become the part of social and religious life of people aggravated the sufferings of women. 'Due to fear of abduction and molestation by Muslim invaders; 
child marriages, purdah system, restriction on free movement of women and their education became an inherent part of medieval Hindu society (Rawat and Kumar 2015, 86). However, in spite of all this deterrence there were many women like Queen Durgawati, Shivaji's mother Jijabai, Ahilya Bai Holkar who were able warriors and administrators. Bhakti movement during this period which tried to 'restore women's status by providing them equal footing with men thus questioning their subservient status and openly advocating equality among men and women' (Rawat and Kumar 2015, 86), saw women like Meera Bai, Akkamahadevi, Habbakhatun and Chandravati.

\section{Women before Independence}

Modern India saw noticeable change in the condition of women with the social reforms in the field of education, opposition of sati system and child marriage, stress on widow remarriage and abolition of purdah system. During the British rule, many reformers like Ram Mohan Roy, Ishwar Chandra Vidyasagar and Jyotiba Phule fought tirelessly for the upliftment of women. Christian missionaries spread education among women. Mahatma Gandhi, who did a lot to uplift the downtrodden, instilled a sense of dignity, pride and hope in women by making them participate in the struggle for independence. He was against child marriage, purdah system, dowry system, and advocated widow remarriage. His influence is immense in the improvement of the condition of women in India. 'Women, urban and rural, educated and uneducated, Indian and foreign were attracted to his ideas and deeds. While some like Sarojini Naidu, Lakshmi Menon, Sushila Nayyar and Rajkumari Amrit Kaur rose to prominence, there were thousands of unsung and unnoticed heroines of India who learnt the meaning of liberation from him and contributed with all their energy to the struggle of independence' (Rathi n.d.).

\section{Women after Independence}

Indian women have experienced enormous progress in post independent India. Fortunately, Indian women did not have to fight for the right to vote. 'The Indian constitution guarantees equality to all women (Article 14), there shall be no discrimination by the state (Article 15(1)), equality of opportunity (Article 16) and guarantees equal pay for equal work (Article 39 (d)) (Rawat and Kumar 2015). There have been several campaigns and schemes from the government for awareness and improvement in the condition of women. Some of them are Beti Bachao, Beti Padao (Save the Daughter, Educate the Daughter), Sakshar Bharat (Literate India) Mission for Female Literacy, SABLA- Rajiv Gandhi Scheme for Empowerment of Adolescent Girls, National Programme for Education of Girls at Elementary Level. There are reserved spots for women in nearly all the government provided employment opportunities. Women have active participation in each and every field, be it politics, economy, public and private sectors, sports, science or media. Besides this there are many NGOs spreading awareness, and fighting against domestic violence, dowry deaths, rape, female foeticide and gender rights. Nonetheless, there are several instances showing gender discrimination and exploitation to be still common in Indian society.

The biggest paradox found in the Hindu society is its general attitude towards women. On one hand Goddesses are worshipped (Shakti or Durga being the most important) in every house, nine days fasts are observed with great faith, by both men and women, Durga pooja is celebrated with much fervour and gaiety, hymns are chanted from the book of Durga Saptashati, girls become the symbol of the Goddess Herself and are literally worshipped in many households, but on the other hand, ironically enough and contradictory to this, women are the victims of everyday domestic violence. Women have always been considered the weaker sex, emotionally, intellectually, as well as physically by the patriarchal society.

'Government runs according to the written law whereas society is controlled by unwritten traditions' says Mahadevi Verma (1969, 384), an eminent writer. Indian society is still bound by age long religious beliefs (distorted and appropriated by kings and other powerful castes for their own advantages), which still consider women inferior to men. The Upanayan Sanskar which after early Vedic period was denied to women still has its repercussions all over. According to 2011 census the male literacy rate in India is $82.14 \%$ whereas the female literacy rate is $65.46 \%$ only. This huge disparity in literacy rates can be attributed to poverty as well as the attitude of the parents 
who somehow manage to send their boys to school but restrict and dedicate their girls to mere household duties which reaffirms the age old belief that women are for hearth, and should be expert in domestic works. Another factor which plays against women is her perception as a non-earning member of the family, and it is considered an additional financial burden to educate a girl who later on will be married into another family with huge sums of money as dowry. Yet another factor which adds to the low literacy rate of women in India is the location of the schools, which makes it hard (due to safety reasons) for a girl child to cover a long distance to attend school every day. However, it must be kept in mind that by devoiding half of the population of its education, a nation cannot be strong. An educated woman is not only an asset to the family but also to the nation building process. Getting educated is the strongest way for women to get rid of their inferiority which has been instilled in women since long. Mary Wollstonecraft (1988, 141), strongly advocating women's education in her famous book $A$ Vindication of the Rights of Woman writes "There must be more equality established in society, or morality will never gain ground, and this virtuous equality will not rest firmly even when founded in a rock, if one half of mankind be chained to its bottom by fate."

Another serious problem faced by Indian society is the sex ratio of India, which according to the census of 2011 is 943 females per 1000 males. This trend has been more or less the same after independence. The main reason has its deep and strong roots in socio religious beliefs, which would need not years and rather decades to diminish. The birth of a male child is rejoiced in a family for several reasons. Some of these find expression in age old Puranas (Garud Purana) and Manu smriti where the right of performing last rites as well as the shraddh and pind daan of the parents is exclusive right of the male child. These performances are a must for attaining salvation, which for Hindus is the ultimate objective of life. The son is responsible for extending the family tree whereas a girl child is considered to be 'paraya dhan' (others property) from the beginning only. However, this strong perception is losing grounds day by day, with women becoming educated, getting employed and thus, in this way, proving themselves to be 'sons' to their parents.

One of the recent cases of Sabrimala Temple which made media headlines in 2018, led to a women's revolt, is one of the incidents of its own kind against the socio-cultural beliefs and its sanctions on a woman's body by patriarchal society. Sabrimala Temple is a famous temple of Ayappa in the Kerala state of India, and is the site of one of the largest annual pilgrimages in the world. In the year 1991 Kerala High Court denied the entry of women above ten and below fifty years of age to the temple. 'In its verdict, the Kerala High Court mentioned that the ban on women entering the Sabrimala Temple had existed since time immemorial and only the "tantric" (priest) was empowered to decide on traditions. This however was "challenged by a group of women lawyers on the ground that banning women from visiting a public place of worship was a violation of ideals of equality, non-discrimination and religious freedom' (The Times of India 2018). The case reached to the Supreme Court of India, and the bench of five judges, on the 28th of September 2018, lifted the ban on the entrance of women in the temple. This was a great triumph of Indian Constitution as well as Indian women against patriarchy through culture and religion. Noticeably, the men judges ( 4 in number) in the five judge bench in this case showed extraordinary wisdom and strength of character in delivering a judgement unforeseen and unheard before. Justice Chandrachud wrote in his judgement:

To exclude women from worship by allowing the right to worship to men is to place women in a position of subordination. The constitution should not become an instrument for the perpetuation of patriarchy. (Mishra 2018).

He very categorically remarked: Women have a right to control their own bodies. The menstrual status of a woman is an attribute of her privacy and person. Women have a constitutional entitlement that their biological processes must be free from social and religious practices, which enforce segregation and exclusion' (kini, livelaw, web).

Taboos based on menstruation are common in every religion. However, it is to be noted that in Hindu culture, early Vedic texts are silent about these prohibitions. It's the later Vedic texts or Smritis like Aangirasa smriti and Aapsthamba smriti which mention restrictions towards women 
based on menstruation. The menstrual blood of women, according to these Smritis is based on the myth of Indra killing an ungendered being (later transformed by certain texts into a Brahman) whose sin is shared by women. Most of the Hindu women still follow restrictions based on religious beliefs of menstruation. Some of these restrictions include segregation of women (specific place, utensils, bathing restrictions), restriction of movement (to kitchen, temples etc). These are more strenuously followed in the rural parts as compared to urban societies. In rural areas, especially in mountain regions where the temples of local gods are common along the walkways/pathways, school going girls are forced to stay home during their menstrual cycle. In some regions menstrual huts/rooms have been built to isolate the menstruating women from rest of the village. Women are also known to have been living in cowsheds during this period. Noteworthy is however, the swiftness and strictness shown by the law enforcement for these kind of inhumane restrictions. In recent times, any such cases are dealt with promptness and are severely punished by the law.

\section{Conclusion}

Unfortunately, many women have internalised the idea of inferiority, physical or mental, propagated and appropriated by patriarchy since ages through religion and traditional practices. The need is to redefine the subjectivity which has been for long defined by men for women. We must think '...how our femininity and sexuality are defined for us and how we might begin to redefine them for ourselves' (Weedon 1987, v). The crucial factors for change in the condition of women in India are education, employment and mobility. Virgina Woolf $(2005,2)$, a famous British writer and critic emphasises on economic independence. She writes, 'a woman must have money and a room of her own if she is to write fiction.' Access to education, which was long ago taken away from women, can bring about immense change in the condition of women. Indian society which has been blinded long enough by the distortions and corruptions in the original Vedic religion/scriptures, must take its cue from early Vedic period for an egalitarian society in changing times and contexts.

\section{References}

Atharva, Ved. 2014. Edit. Pdt. SriRam Sharma Acharya, Bhagwati Devi Sharma. Mathura: Yug Nirman Yojna Vistaar Trust.

Beauvoir de Simone. 1997. The Second Sex. Trans. H.M.Parshley. Vintage: London.

Bhikkhu, Thanissaro. 2005. "Therigatha: Verses of the Elder Nuns." Edited by Access to Insight. Access to Insight (BCBS Edition), 30 November 2013, http://www.accesstoinsight.org/tipitaka/kn/thig/index.html.

Buhler, G. 1886. The Laws of Manu, Trans. Clarendon Press, Oxford.

Das Sukla. 1993. "Status of Women in the Vedic Period: Genesis and Gender Polarity." In Dimensions of Indian Womanhood. Ed. C.M. Agrawal. Volume III. Almora: Almora Book Depot.

Garud, Purana. 2010. Gita Press, Gorakhpur.

Kane, PV. 1974. History of Dharmasastras, Volume II, Part I. Bhandarkar Oriental Research Institute: Poona.

Kini, Ashok. 2018. "Social Exclusion Of Women, Based On Menstrual Status, Is A Form of Untouchability." Live Low. Available at: https://www.livelaw.in/social-exclusion-of-women-based-on-menstrual-status-is-a-form-ofuntouchability-justice-dy-chandrachud/.

Mishra, Soni. 2018, September 28. "Sabrimala verdict: How Supreme Court sought to quash patriarchy in religion." The Week. Available at: https:/www.theweek.in/news/india/2018/09/28/Sabarimala-verdict-Patriarchy-inreligion-cannot-be-allowed-writes-CJI-Misra.html.

Murray, M Jr. 1994. Status and Sacredness: A General Theory of Status Relations and an Analysis of Indian Culture. Oxford University Press: Oxford.

Rathi, Subhangi. n. d. Gandhi and Women Empowerment. Available at: https://www.mkgandhi.org/articles/women_empowerment.htm.

Rawat and Kumar. 2015. "Hindu Women in the Mirror of Time: At Once a Goddess and Slave?" Journal of Indian Research, Vol. 3, July-September, 2015.

Rg Veda Samhita. 2014. Edit. Pdt. SriRam Sharma Acharya, Bhagwati Devi Sharma. Mathura: Yug Nirman Yojna Vistaar Trust.

Roy, Aparna, 2012. Women in Purana Tradition. Raka Prakashan: Allahabad

Singh, Dilip KS. 2004. Kutch in Festival and Custom. Har Anand Publications: New Delhi.

Tandon, Neerja. 2016-2017. Ikkiswin Sadi ke Sarokaar aur Stri Vimarsh ka Yatharth. Research Project sponsored by Kumaun University.

Tharu, Susie and K. Lalita. 1991. Ed. Women Writing in India, Vol.I. 600 B.C. to the Early $20^{\text {th }}$ Century. Bombay: Oxford University Press. 
The Times of India. 2018. "What is Sabrimala case?" October 3, 2018. India News-. https://timesofindia.indiatimes.com.

Verma, Mahadevi. 1969. Mahadevi Sahitya Samagra. Ed. Nirmala Jain. New Delhi: Vani Prakashan.

Weedon, Chris. 1987. Feminism and Theory. Oxford: Blackwell Publishers.

Wollestonecraft, Mary. 1988. A Vindication of the Rights of Woman. Ed. Carol H. Poston, A Norton Critical Edition (Second). New York: W.W. Norton and Company.

Woolf, Virgina. 2005. A Room of One's Own. New Delhi: U.B.S Publishers Distributors Pvt. Ltd. 